\title{
The iron-glass roof of the Milan Gallery Vittorio Emanuele II: knowing the past, understanding the present and preservation for the future
}

\author{
I. Stoyanova \\ Department of Architecture and Urban Studies, \\ Polytechnic University of Milan, Italy
}

\begin{abstract}
Past research discussed the genesis of the Milan Gallery Vittorio Emanuele II and its importance as an emblematic example of $19^{\text {th }}$ century glazed arcades. The iron-glass cover was hailed as a significant technological accomplishment at the time. Previous personal studies highlighted the reinforcing system which integrated the iron roof into the surrounding masonry structures and the glazing system as characteristic technological aspects which were closely related to the monumental vocation of the Gallery and survived until the present day.

This paper deepens the knowledge on the reinforcing and the glazing systems respectively as solutions for lateral thrust management and as a complex of glazing techniques which obtained architectural value in the case of the Gallery. The introduction outlines the complex Gallery genesis in relation to its monumental vocation. The paper then explains the elements and the logic of the two systems in view of the $19^{\text {th }}$ century building practice. Next, these studies argue that the roof reconstruction after the Second World War conserved the primary roof system and improved the long-term performance of the original glazing technology with technical alterations such as dilatation joints and trapezoidal laps instead of triangular ones. The paper also documents the presentday state of the reinforcing and glazing systems and discusses which aspects complied with the original technology and which were introduced in the postwar reconstruction. Finally, the paper concludes that the two systems represent the conservation and preservation history of the Gallery.

Keywords: Vittorio Emanuele, reinforced masonry, historical iron, cruciform bars, triangular edges.
\end{abstract}




\section{Introduction}

The Milan 'Vittorio Emanuele II' (1865-1877) constitutes an emblematic example of 19th century European glazed arcades which are still standing today, fig. 1. Furthermore, the Gallery has recently accomplished 150 years since the first stone was laid on $7^{\text {th }}$ March 1865. The layout is in the shape of a Latin cross which comprises two perpendicular wings surrounded by masonry buildings, fig. 2. The main branch connects Piazza del Duomo with Piazza della Scala as two of the landmarks of Milan social, religious and cultural life. The Gallery is covered with a glazed iron roof which comprises four vaults over the wings and a monumental cupola over the octagonal intersection. All of these roof parts are topped with lanterns.

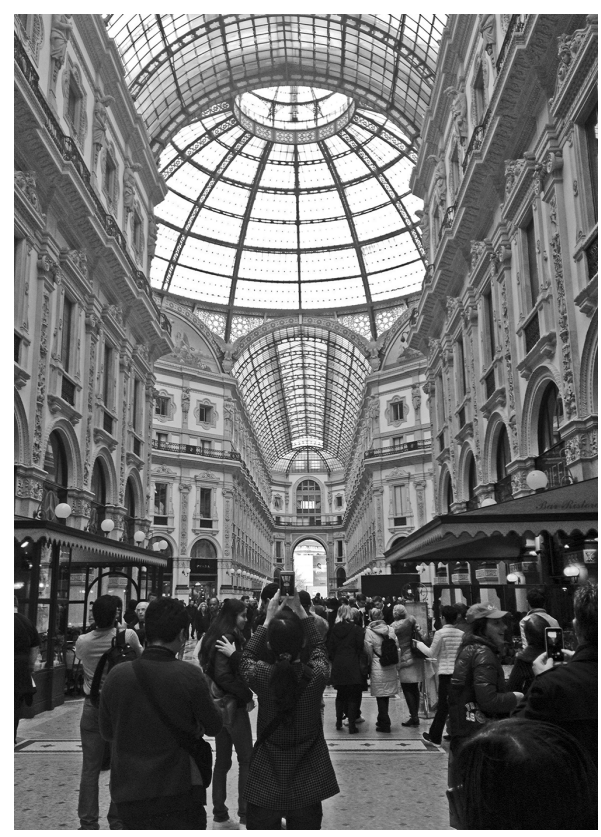

Figure 1: Preview into the Gallery today from the entrance from Piazza del Duomo.

The Milan Gallery marked the monumental phase in the development of the arcade typology according to the classification by Geist [1]. This monumental character was deeply rooted in the complex genesis of the Gallery.

$20^{\text {th }}$ century studies such as Selvafolta [2] and Balestreri [3] discussed how the Gallery developed as an integral part of the projects for a monumental Piazza del Duomo in Milan. These were initiated to create a large representative piazza suitable for the Milan Cathedral. In addition, one of the most renowned Italian architects and architectural historians of the $19^{\text {th }}$ century - Beltrami [4], 


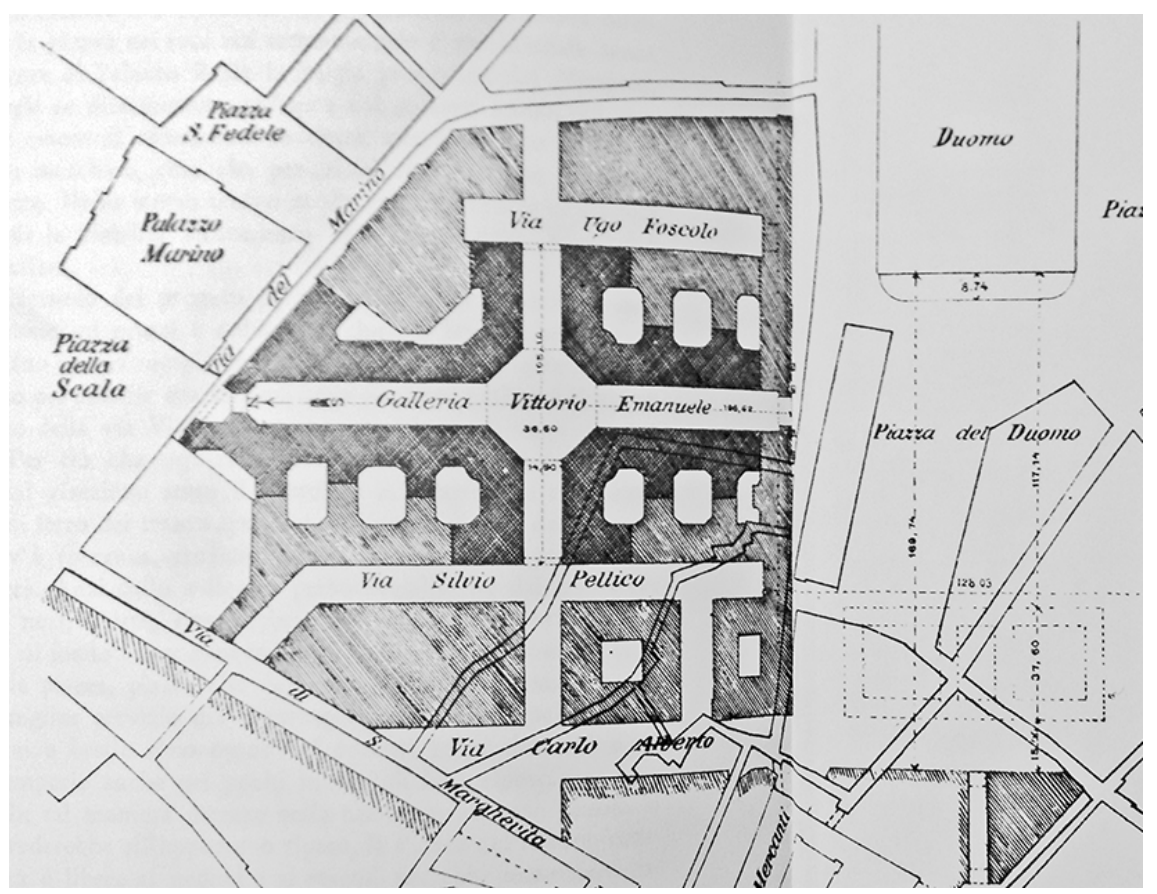

Figure 2: The cruciform layout of the Gallery with the surrounding buildings in the final project of 1864 in Chizzolini and Poggi [8].

interpreted the genesis of the Gallery in close relation to the necessity to "unclog" the urban tissue to the north of the city centre. All these intentions took a more definitive form through a number of projects which were developed in the first half of the $19^{\text {th }}$ century during the Austrian and French reigns in Italy as discussed in various Italian volumes such as Rondello [5], Marchetti [6] and Giulini [7].

The idea for a direct urban connection articulated as a glazed passage connecting Piazza del Duomo with Piazza della Scala crystallized through the municipal competitions of 1860, 1861 and 1863. Unleashed by the impulse to commemorate the achieved Italian independence (1859) and unification (1861), the three contests were aimed at finalizing both the projects for the monumental piazza and for a gallery dedicated to the first king of unified Italy Vittorio Emanuele.

The Bologna architect and engineer Giuseppe Mengoni (1829-1877) constituted another significant factor from the "active ingredients" which synergy resulted in the Gallery as an ambitious architectural phenomenon. His professional zeal and his ability to analyse and combine together efficient solutions in his projects were highlighted in $20^{\text {th }}$ century sources such as Gresleri [9]. Thanks to his international connections, the English Building Society "The City of Milan Improvements Ltd" was founded in 1864 to the specific purpose of funding the construction works for the new piazza and the Gallery as argued in 
Chizzolini and Poggi [8]. Mengoni's role of a mediator between all the protagonists behind the construction works of the Gallery was vastly acknowledged in previous research such as Selvafolta [2].

According to Chizzolini and Poggi [8], the Gallery was celebrated at the time as the first large-scale construction which resorted to the structural adoption of iron in combination with brick masonry for the load-bearing system. This mixed technique was acknowledged in Selvafolta [2] as a "hybrid" of tradition and innovation.

The iron-glass roof of the Gallery constituted one of its main characteristic features. Soon after the Gallery was completed, Jorini [10] discussed the accomplishments of the cupola with special regard to the dimensions (height $11.68 \mathrm{~m}$, diameter $39 \mathrm{~m}$ in Chizzolini and Poggi [8]) and monumental spatial effect of the dome. The cupola was also appreciated in the $20^{\text {th }}$ century volume by Jodice [11] against the panorama of interpretations on the topic of monumental iron domes such as Paris Halle au blè (1809), the one of the London Coal Exchange (1847), of the New York Exposition (1853) and of Dublin (1853), Leeds Corn Exchange (1860) and London Exposition of 1862. The Milan iron-glass cover as an integral part of the Gallery has become a common reference in $20^{\text {th }}$ century literature such as Hitchcock [12] and Pevsner [13] as a significant example of $19^{\text {th }}$ century iron-glass architecture.

The roof construction system comprised primary arches and purlins which upheld the glazing bars and the glass cladding. In addition, an elaborate system of maintenance facilities such as iron boardwalks and sliding stairs was developed onto the glazed roof. The roof ironwork was produced, transported and installed by the French Atelier Henry Joret while the glass plates were supplied by Saint-Gobain Company as explained in Bianchi and Fusarini [14]. Therefore, the Gallery developed as a joint effort with special regard to the ironglass roof technology.

The under-maintained present-day state of the roof alarms towards urgent interventions of different types: from integral substitution of the glass cladding with double-pane laminated glass, as pointed out by Manenti [15], to reinforcements and potential replacements of the ironwork. Before planning any future intervention, it is necessary to take into account the historical value of the iron-glass structure standing in place today.

The system reinforcing the roof span and the glazing system were concluded in previous personal studies [16] as two of the characteristic aspect of the roof which encoded its historical value and survived until the present day.

This paper deepens these two aspects in order to appreciate the logic behind the original solutions as $19^{\text {th }}$ century techniques for lateral thrust management and efficient glazing which in the case of the Gallery contributed to a more ephemeral effect and obtained an architectural value. In addition, this paper explores on the basis of newly discovered original documents and recently conducted personal investigations if/when the reinforcing and the glazing systems went through any historical modifications. The goal is to comprehend which aspects of the two systems in today's roof comply with the original roof technology and which ones were introduced in subsequent interventions. 


\section{The original solutions for lateral thrust and glazing}

\subsection{The combined reinforcing system}

The efficient management of later thrust in the case of thermal expansion of the primary iron arches was pointed out in Chizzolini and Poggi [8]. Chizzolini was the chief engineer of the English Society and ideated the solution.

The general principle exemplified how the iron-masonry "hybrid" functioned with particular regard to the roof structure, fig. 3. The primary arches were rigidly connected to a granite block topping the supporting brick masonry. As Chizzolini himself explained such a solution was contrary to the most diffused one at that time e.g. a mobile connection allowing slight movements in the case of expansions. Then, this rigid connection was combined with four-meter iron ties which braced the granite blocks against the supporting masonry. The iron ties were braced lengthwise in their lower ends with horizontal ones. Thus, in case of expansion the primary arches were constraint to move upwards and the supporting masonry was appropriately reinforced in order to counteract. Any lateral thrust left was transmitted to the surrounding masonry buildings by means of crosswise and lengthwise beams running along the perimeter of the Gallery.

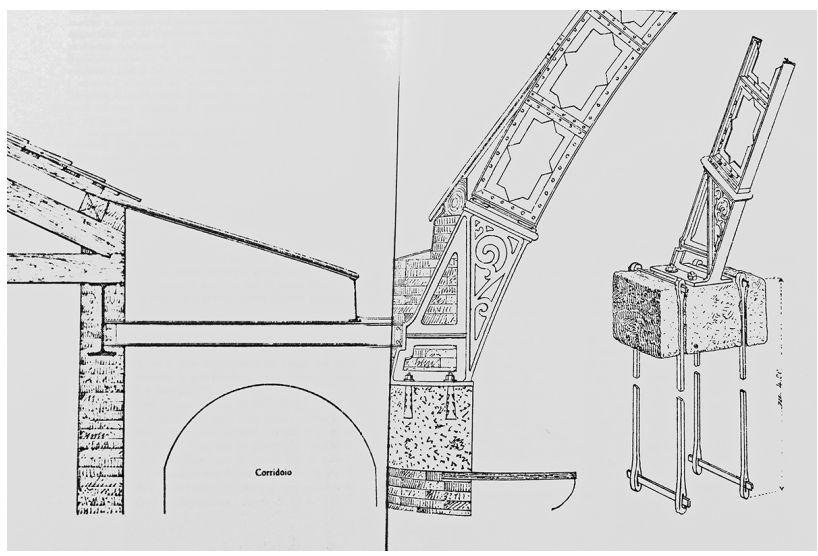

Figure 3: The combined reinforcing system for lateral thrust management at the foot of the primary vault arches in Chizzolini and Poggi [8].

This system was distributed in accordance not only with the primary vault arches but also with those of the cupola as pointed out in Saldini [17]. As further illustrated in Saldini [17] and later in fig. 4, in the case of the prolonged cupola arches behind the decorative lunettes, the crosswise beams of the reinforcing system were paired in order to serve also as supports.

As explained in previous personal research [16], this solution was rooted in the monumental vocation of the Gallery because it had to avoid any visible reinforcing rods in the roof span according to a specific building contract 


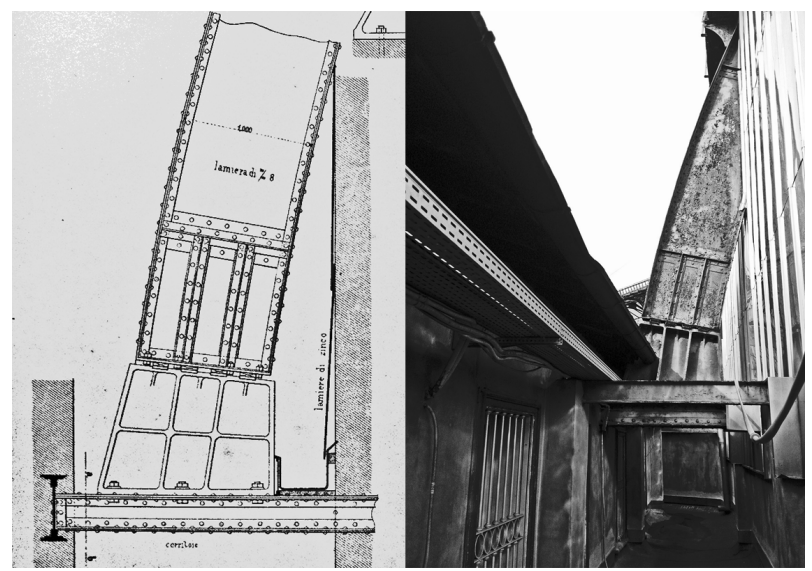

Figure 4: The crosswise reinforcing beams acting as supports at the foot of the primary cupola arches behind the lunettes.

reported in Saldini [17]. According to Chizzolini and Poggi [8], such visible reinforcements would have been inappropriate in such a monumental space.

This solution should be appreciated in view of the conclusion by Geist [1] that 'Vittorio Emanuele' doubled the span $(14.96 \mathrm{~m})$ and the height $(25.07 \mathrm{~m})$ in comparison to already existing arcades. The cupola was claimed in Jorini [10] to be one of the largest iron domes completed up to that moment.

In addition, the reinforcing system should be considered in relevance to another disadvantageous factor: the vault represented in cross section a circle segment. Such geometry was pointed out by Eck [18] as one of the most unfavourable cases for curved roofs. It predetermined a larger horizontal component of the roof load than the pointed arc for example and thus incremented lateral thrust already on the level of the overall roof geometry.

A crucial condition pointed out by Oslet [19] for efficient performance was the combination of a rigid connection with well-reinforced masonry supports. As reported in Donghi [20], such a solution illustrated two of the most diffused assumptions about lateral thrust in the second half of the century. First, the lateral thrust of iron roofs was considered as significantly smaller than that of iron bridges and therefore, it was also possible to adopt a rigid connection instead of a mobile one. In addition, reinforced masonry was also employed as a precaution against the incalculable wind forces which were especially unfavourable in the case of covered spaces.

\subsection{The ephemeral effect of the glazing}

One of the particularities of the glazing bars concerned their role of crosswise supports for the maintenance facilities. According to the technical report on the roof by Bianchi and Fusarini [14], these facilities had to be supported by the primary roof system and especially by the lengthwise purlins in the case of the stairs. 
However, it was possible to individuate through archival photographs documenting the installation of the glass cladding that the rails of the sliding stairs were supported crosswise also by the glazing bars. Therefore, the glazing bars had to reconcile both demands for small dimensions and higher resistance set by the dead and live loads of the sliding stairs.

T-profile glazing bars employed for the cupola glazing were illustrated in Saldini [17]. In previous personal research [16], it was discussed if different glazing bars were employed for the vaults, the cupola and the lanterns.

The current research managed to expand this knowledge through the five graphic tables with which the Atelier Joret participated the World Exposition in Paris of 1867 as pointed out by Geist [1]. As a result, it was uncovered that the glazing bars which were integrally employed for the glazing of the vaults, their lanterns and the cupola lantern represented a cruciform section.

In the history of glazing sashes, the cross section evolved from a composite profile towards a rolled one and then towards a cruciform geometry as pointed out in Kohlmaier and Von Sartory [21]. As reported also in Donghi [20], Denfer [22] and Vierendeel [23], the cruciform profile gained considerably more stiffness over the T-profile since its geometric centre was located in the middle unlike the one of the $\mathrm{T}$ sections. Therefore, cruciform glazing bars were much more suitable for the elevated resistance requirements in the Gallery roof. If it is assumed that the glazing bars supported also the maintenance facilities of the cupola, it can be also suggested that cruciform sections were eventually employed instead of the alleged T-like ones.

The glass plates supplied by the Saint-Gobain company were made of ribbed flat glass as pointed out in Chizzolini and Poggi [8] and represented the most widely diffused type in the Italian practice of glazed roofs according to Königer [24]. In the Gallery case, there were two prevailing length types of $0.88 \mathrm{~m}$ and $1.70 \mathrm{~m}$ according to Bianchi and Fusarini [14] but all the glass plates shared standard width of $0.6 \mathrm{~m}$ and thickness of $6 \mathrm{~mm}$.

The adoption of laps was another characteristic feature reported in Königer [24] with reference to the Saint-Gobain glass plates in $19^{\text {th }}$ century Italian glazing practice. Curved bottom edges of the plates were stated as the most common ones but in the case of the Gallery the laps were V-shaped. The glass panes were secured in their lower edges to the glazing bars with metal fixings and were then sealed with putty according to the graphic tables in Saldini [17].

These glazing techniques had already been established in the common glazing practice of the $19^{\text {th }}$ century. Small but resistant glazing bars and the laps of the glass plates had been widely discussed in hothouse literature such as in Loudon [25] and McIntosh [26] with special regard to the issues of maximum airtightness, condensation, water expansion and dirt or moss deposits. However, in the specific case of the Gallery and its monumental vocation, the complex of these glazing solutions needs to be appreciated in view their combined ephemeral effect through which they gained also an architectural value.

The delicate glazing bars increased the transparent area of the cover. The Vshaped laps created a certain perspective effect desired by Mengoni for the viewer according to the documentation on the roof post-war reconstruction. The 
perception of this decorative effect was not obstructed by additional iron sections at the crosswise edges of the glass plates as it was in previously constructed arcades with smaller span. For example, in the cases of the Paris Galerie D’Orléans (1828-1829) and the Brussels Royal Galleries Saint-Hubert (18451847) such sections were necessary also for the lengthwise bracing of the entire roof structure. In the Milan roof such functions were executed by the primary system and the purlins in particular.

\section{Historical modifications and present-day state}

Personal archival studies revealed that the damage during the Second World War bombardments (August 1846) and the subsequent reconstruction of the roof resulted in the first modifications of the original technology and of the original iron structure. The interventions in the roof before and after that constituted cases of routine and special maintenance. They involved repeated substitutions of glass plates and repainting of the iron structures.

The post-war interventions in the primary iron roof included the substitution of the heavily damaged components while those reparable were conserved and reinforced in-situ according to Carpinelli [27]. The irreversible damage on the glazing bars and the glass plates necessitated their entire substitution. After passionate discussions if the adoption of cement and glass was more appropriate for the purposes of easier maintenance, it was decided to employ iron and glass and to follow the same glazing technology as pointed out in Rondello [5].

Nevertheless, modifications were introduced in order to "heal" those aspects of the original construction details which had emerged as defects during the roof maintenance history. These alterations were carefully designed and did not compromise the architectural value behind the ephemeral glazing. Yet, they improved the long-term performance of the glazed roof.

Therefore, in the roof today can be recognized both $19^{\text {th }}$ and $20^{\text {th }}$ century ferrous structures as well as aspects of the original roof technology and modifications introduced in the post-war reconstruction.

The $19^{\text {th }}$ century ferrous structures of the reinforcing beams as cupola supports can be observed on site, fig. 4. The place where the reinforcing system in particular could have been modified or replaced with replicas concerns the most heavily damaged in the war short vault towards Ugo Fuscolo Street.

It is necessary to test the structural stability of the reinforcing system and the supports and the quality of the historical iron. The $19^{\text {th }}$ century ferrous structures were already examined at the turn of the 1970s and represented acute signs of material brittleness and vulnerability to unpredicted impact loads according to Vallatta [28]. The invisible historical iron beams and ties reinforcing the supporting masonry need to be also investigated onsite preferably with nondestructive techniques.

The new glazing bars were designed with a cruciform section in order to reconcile requirements for small dimensions and high load-bearing capacity. As it was explained in Carpinelli [27], the delicate parameters were necessary in order to decrease the employment of iron and the dead load of the glazing bars 
onto the conserved in-situ primary system. The cross section of the new profile in fig. 5 was elaborated on the basis of the graphic information reported by Rondoni [29].
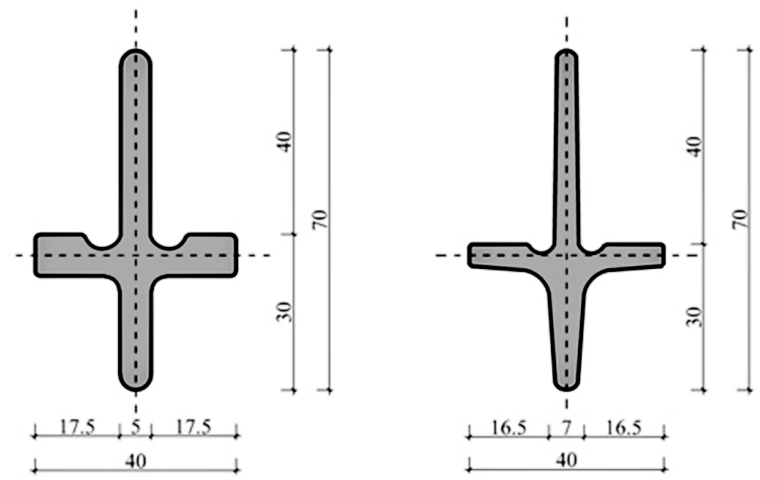

Figure 5: Parallel between the original cruciform section of the glazing bars and the one introduced in the post-war reconstruction.

The new sliding stairs were designed with supports only onto upper and lower rails in order to avoid the numerous breakages of glass plates due to the sliding of the stairs as explained in Carpinelli [27], fig. 6.

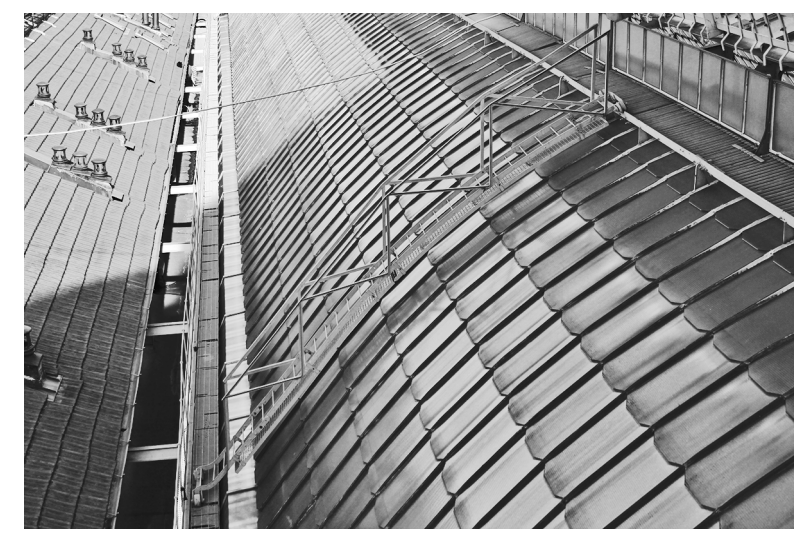

Figure 6: The new sliding stairs over the vaults and the supports onto the rails in the upper and lower ends.

Another improvement was the introduction of dilatation joints in the connection between the glazing bars with the supporting purlins, fig. 7. Thus, the original imbedded solution was altered since the different dilatation coefficients of the glazing bars and the purlins were claimed to result in repeated glass breakages. 

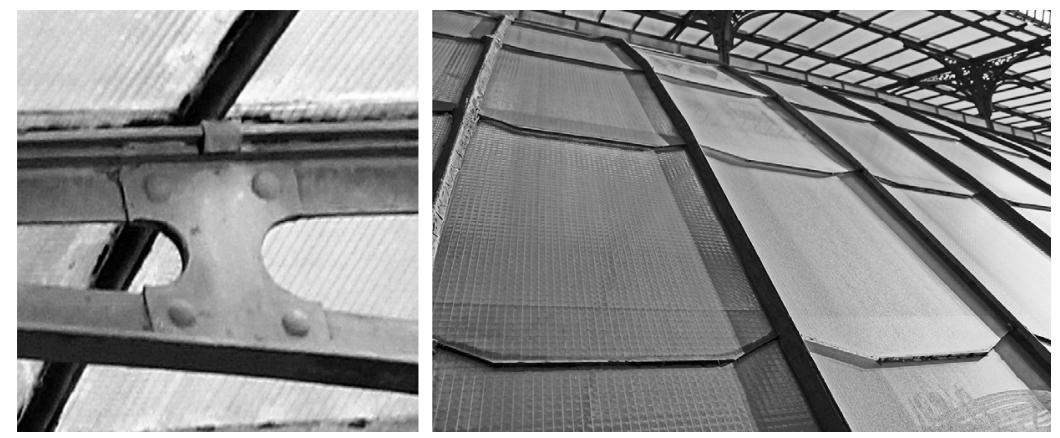

Figure 7: The dilatation joints in the connection of the glazing bars with the purlins and the trapezoidal laps probably introduced in the post-war reconstruction. The recent adoption of laminated glass can be also noted to the right.

The majority of glass plates standing in place today can be dated back to the last large-scale maintenance campaign of the 1980s. During it the entire glass cladding was substituted with wired glass plates as reported by Gianni [30]. In addition, double-pane laminated glass plates were introduced most recently, fig. 7.

The difference in geometry between the original glass plates and those in place today concerns the modification of the $\mathrm{V}$-shaped lap into a trapezoidal one, figs 6 and 7. Archival research so far did not uncover any specific documentation on the date and the motivations behind such an alteration. Nevertheless, the few photographs of the reconstructed roof display a trapezoidal rather than a triangular bottom edge. Therefore, it can be assumed that it was introduced in the post-war reconstruction. Such a modification can be explained with the technical advantages of the trapezoidal shape in water-draining. The V-like edge concentrated the water stream in the central zone and favoured dirt and rust deposits on both sides of it while the trapezoidal lap dispersed the stream.

\section{Conclusions}

The historical value behind the combined system for lateral thrust can be found in several aspects. The collaboration of iron and masonry produced an efficient alternative of the usual horizontal rods and at the same time solved the problem with the incalculable wind forces. This system survived into the present day roof not only as a complex of techniques but also as original materials and elements. The fact that these elements still continue to balance the lateral thrust of the roof turns them into the material prove for the successfully met challenges by the roof technology 148 years ago. Nonetheless, the acute issues of material brittleness, corrosion and stability urges towards further and more precise investigations as soon as possible.

The historical value behind the complex of glazing techniques present in the roof today can be concluded on two main levels. First, they are in continuity with 
the original glazing technology thanks to the post-war reconstruction criteria which promoted the original glazing techniques and types of materials. Second, the original glazing solutions exemplified how common $19^{\text {th }}$ century glazing techniques gained architectural value with specific regard to the monumental vocation of the Gallery.

On this account, it can be concluded that both the reinforcing and the glazing systems have multi-fold historical value. It is rooted not only in the compliance with the original roof technology and materials but also in their quality of technological aspects which encoded the conservation and preservation history of the Gallery.

\section{References}

[1] Geist, J. F., Arcades: The History of a Building Type. MIT Press: Cambridge, Massachusetts, 1985.

[2] Selvafolta, O., La Galleria Vittorio Emanuele. Aspetti e problemi di storia edilizia, ed. A. Castellano \& O. Selvafolta, Electa: Milano, pp. 221-265, 1983.

[3] Balestreri, I., I progetti per Piazza del Duomo a cavallo dell'Unità nazionale. Eredità, prospettive, proposte e discussioni. Architettura a Milano negli anni dell'Unità, ed. M. Grandi, Libraccio: Milano, pp. 12762, 2012.

[4] Beltrami, L., Vicende edilizie della Piazza del Duomo di Milano in L’Edilizia Moderna, 5(2, 3), pp. 10-12, 18-20, 1896.

[5] Rondello, A., La galleria Vittorio Emanuele 2. Itala ars: Milano, 1967.

[6] Marchetti, L. La galleria di Milano. A. Cordani: Milano, 1967.

[7] Giulini, G., La piazza del Duomo di Milano. Libreria editrice milanese: Milano, 1927.

[8] Chizzolini, G. \& Poggi. F., Piazza del Duomo e Galleria Vittorio Emanuele. Milano tecnica dal 1859 al 1884, Ulrico Hoepli: Milano, pp. 195-220, 1885.

[9] Gresleri, G., Un capitolo dell'architettura moderna non ancora scritto. La Galleria Vittorio Emanuele e l'Architetto Mengoni. Andalò, L. \& Criscione, C., (eds). La Mandragora: Imola, pp. 19-30, 1997.

[10] Jorini, A. F., La cupola della Galleria Vittorio Emanuele II a Milano. L'Edilizia Moderna, 1(2), pp. 4-6, 1892.

[11] Jodice, R., L'architettura del ferro. L'Italia, 1796-1914. Bulzoni: Roma, 1985.

[12] Hitchcock, H-R., Architecture: Nineteenth and Twentieth Centuries. Penguin books: Harmondsworth, 1985.

[13] Pevsner, N., A History of Building Types. Princeton University Press: Princeton, JC, 1976.

[14] Bianchi, G. \& Fusarini, A., Perizia della Copertura in ferri e vetri della Galleria Vittorio Emanuele, 1868 (Archivio Storico Civico di Milano, folder 1382, file 2). 
[15] Manenti, A., Personal communication. 18 November 2014, Architect in charge, Comune di Milano, Settore Demanio e Patrimonio, Milan, Italy.

[16] Stoyanova. I., Promoting a Nineteenth Century Italian Technology: the Crystal Skies of the Milan Gallery Vittorio Emanuele II. Built Heritage: Monitoring Conservation Management, eds. L. Toniolo, pp. 257-270, 2013.

[17] Saldini, B., La copertura della Galleria Vittorio Emanuele di Milano. L'architettura del ferro: raccolta di motivi per costruzioni civili, ferroviarie ed artistiche compilata col concorso dei migliori ingegneri, architetti e costruttori italiani, Saldini, B., (eds). Prem. Litog. e Tipog. degli ingegneri: Milano, 1885.

[18] Eck, L. G., Traite de l'application du fer, de la fonte et de la tôle dans les constructions civiles, industrielles et militaires. (Volume 2). CarilianGoeury et V.or Dalmont: Paris, 1841.

[19] Oslet, G., Traité de charpente en fer. Fanchon et Artus: Paris, 1898.

[20] Donghi, D., Materiali, elementi costruttivi e finimenti esterni delle fabbriche (Volume 1). Manuale dell'architetto. Unione tipograficoeditrice: Torino, 1906.

[21] Kohlmaier, G. \& Von Sartory, B., Houses of Glass: A Nineteenth Century Building Type. MIT Press: Cambridge, MA, 1991.

[22] Denfer, J. Architecture et constructions civiles. Charpenterie métallique (Volume 1). Gauthier-Villars: Paris, 1894.

[23] Vierendeel, A., La construction architecturale en fonte, fer et acier. Paris, Vve. Ch. Dunod: Louvain, A. Uystpruyst, 1902.

[24] Königer, O., Costruzioni in ferro (Volume 3). Trattato generale di costruzioni civili con cenni speciali intorno alle costruzioni grandiose: guida all'insegnamento ed allo studio, G. A. Breymann (eds), Vallardi: Milano, 1877.

[25] Loudon, J. C., An Encyclopædia of Gardening. Longman, Rees, Orme, Brown, Green, and Longman: London, 1835.

[26] McIntosh Ch., Book of the Garden (Volume 1). Blackwood \& Sons: Edinburgh, 1853.

[27] Carpinelli, G., Dichiarazioni dell'ing. Giovanni Magnaghi. Ripresa Nazionale, 2(2), pp. 57-58, 1949.

[28] Vallatta, A., Relazione sullo stato delle strutture in ferro della copertura della Galleria Vittorio Emanuele II. Municipality di Milano: Milano, 1981.

[29] Rondoni, A., Il cielo di vetro della Galleria Vittorio Emanuele. Rassegna dei beni culturali: gestione, restauro, conservazione, protezione, sponsorizzazione, 1(2), pp. 47-50, 1989.

[30] Gianni, G., Restauro della Galleria Vittorio Emanuele II a Milano. I materiali metallici negli interventi di restauro e recupero edilizio: atti del convegno e mostra, eds. M. G. Gimma., BetaGamma: Roma, pp. 197-203, 1989. 